Phinisi Integration Review
Vol. 2, No.2, Agustus 2019 Hal 201-217
Website: $\underline{\text { http://ojs.unm.ac.id/pir }}$
p-ISSN: 2614-2325 dan e-ISSN: 2614-2317
DOI: https://doi.org/10.26858/pir.v2i2.9992

\title{
Pemenuhan Hak Mendapatkan Pelayanan Kesehatan dan Makanan Bagi Deteni di Rumah Detensi Imigrasi Makassar
}

\author{
Andi Samsul Alam \\ Pendidikan Hukum dan Kewarganegaraan, Fakultas Ilmu Sosial Universitas Negeri Makassar \\ e-mail: andisamsulalamsul@gmail.com
}

\begin{abstract}
Abstrak. Penelitian bertujuan untuk mendiskripsikan aturan hukum yang mengatur warga negara asing (Deteni), selain itu untuk mengetahui pemenuhan hak mendapatkan pelayanan kesehatan dan makanan, setra untuk mendalami faktor yang mempengaruhi pemenuhan hak mendapatkan pelayanan kesehatan dan makanan bagi Deteni di Rumah Detensi Imigrasi Makassar. Penelitian ini menggunakan penelitian kualitatif deskriptif. Pengumpulan data dengan observasi, wawancara, dan dokumentasi. Temuan penelitian menunjukkan, 1) Pengaturan hukum Warga Negara Asing (Deteni) diatur didalam Undang-Undang Nomor 6 Tahun 2011 Tentang Keimigrasian, Peraturan Pemerintah Nomor 31 Tahun 2013, Peraturan Menteri Hukum dan Hak Asasi Manusia Nomor 4 Tahun 2017 tentang Tata Cara Pengawasan Keimigrasian, dan Peraturan Direktur Jendaral Imigrasi Nomor IMI.1917OT.02.01 Tahun 2013 Tentang Standar Operasional Prosedur Rumah Detensi Imigrasi, 2) Pemenuhan hak mendapatkan pelayanan kesehatan bagi Deteni di Rumah Detensi Imigrasi Makassar sudah Optimal. Sedangkan pelayanan makanan bagi Deteni di Rumah Detensi Imigrasi Makassar, Kurang optimal., 3). Faktor yang mempengaruhi pemenuhan hak mendapatkan pelayanan kesehatan dan makanan bagi Deteni di Rumah Detensi Imigrasi Makassar, meliputi beberapa faktor, diantaranya yaitu, a) Faktor pendukung sebagai berikut; 1. Pegawai Rumah Detensi Imigrasi Makassar yang memadai, b) Faktor penghambat sebagai berikut; 1 . Anggaran yang terbatas dan 2 . keterbatasan sarana dan prasarana.
\end{abstract}

Kata Kunci: Pelayanan, Kesehatan, Makanan, Deteni

\begin{abstract}
This study aims to describe the legal rules governing foreign citizens (Detainees), in addition to knowing the fulfillment of the right to health and food services, to explore the factors that influence the fulfillment of the right to receive health and food services for Detainees at the Makassar Immigration Detention Center. This study uses descriptive qualitative research. Data collection is done by observation, interviews, and documentation. Research findings show, 1) Legal arrangements of foreign citizens (detainees) are regulated in Law Number 6 of 2011 concerning Immigration, Government Regulation Number 31 of 2013, Regulation of the Minister of Law and Human Rights Number 4 of 2017 concerning Procedures for Immigration Supervision, and the Director General of Immigration Regulation Number IMI.1917-OT.02.01 of 2013 concerning Standard Operating Procedures for Immigration Detention Centers, 2) Fulfillment of the right to health services for Detainees at the Makassar Immigration Detention House. While food services for Detainees at the Makassar Immigration Detention Center, are not optimal., 3). Factors that influence the fulfillment of the right to get health and food services for Detainees at the Makassar Immigration Detention Center, include several factors, including, a) Supporting factors as follows; 1. Adequate Makassar Immigration Detention House staff, b) Obstacle factors as follows; 1. Limited budget and 2. limited facilities and infrastructure.
\end{abstract}

Keywords: Services, Health, Food, Detainees 


\section{PENDAHULUAN}

Arus globalisasi dan perkembangan informasi serta perbedaan geografis, iklim, budaya dan kekayaan alam yang ada di dunia saat ini, menyebabkan setiap negara saling membutuhkan. Dengan demikian setiap negara dipacu untuk turut aktif dalam pergaulan antar bangsa. Kerjasama antar bangsa yang semakin meningkat dan kemajuan teknologi yang semakin canggih, menyebabkan peningkatan arus lalu lintas manusia antar negara.

Secara geografis, letak Indonesia sangat strategis karena diapit oleh dua benua dan dua samudera. Benua yang mengapit Indonesia adalah benua Asia dan Australia. Sedangkang samudra yang mengapit wilayah Indonesia adalah samudera Hindia dan samudera Pasifik. Indonesia memiliki wilayah daratan yang berbentuk gugusan-gugusan pulau. Terbentang dari Sabang hingga Merauke dan dipisahkan oleh laut-laut di antara pulau-pulaunya. Sebagai negara kepulauan, Indonesia diuntungkan memiliki tiga jenis wilayah yaitu wilayah darat, laut dan udara yang mungkin tidak semua negara memilikinya

Negara Indonesia memiliki posisi yang sangat strategis dalam transportasi dan perdagangan internasional, yang mengakibatkan arus lalu lintas orang masuk dan keluar wilayah Indonesia semakin meningkat. Semakin terbuka lebarnya jalur lalu lintas antar negara pada saat ini menyebabkan meningkatnya pula mobilitas barang dan manusia antar satu negara ke negara lain. Dalam memenuhi kebutuhannya, secara tidak langsung negara membuka lebar pintu masuk dan akses ke dalam ruang lingkup batasan negara. Masing-masing individu juga dengan mudah melakukan perjalanan dari satu negara ke negara lain.

Bersamaan dengan perkembangan di dunia internasional, telah terjadi perubahan didalam negeri yang telah mengubah paradigma dalam berbagai aspek ketatanegaraan seiring dengan bergulirnya repormasi disegala bidang. Perubahan yang terjadi telah membawa perubahan dan pengaruh yang sangat besar terhadap terwujudnya persamaan hak dan kewajiban bagi setiap warga negara sebagai bagian dari hak asasi manusia.

Indonesia merupakan negara yang berdasar hukum bahwa segala aspek kehidupan dalam kemasyarakatan, kenegaraan dan pemerintahan harus senantiasa berdasarkan atas hukum. Hal ini membawa konsekuensi hukum bahwa dalam negara hukum Indonesia, penyelenggaraan kekuasaan negara dalam arti luas harus dan senantiasa berdasar pada hukum, sebab hukum itulah yang memberi legitimasi sekaligus memberikan batas-batas yang menjadi wewenang negara. Hukum memberikan pula perlindungan terhadap hak-hak asasi warga negara dari kemungkinan adanya pelanggaran dalam penggunaan kewenangan tersebut. Adapun mengenai hak-hak asasi itu sendiri dalam pemberian interpretasi atau maknanya selalu diletakkan dalam kerangka pandangan hidup dan budaya serta cita-cita hukum dari bangsa dan negara atau yang disebut hak dan kewajiban warga negara telah tercantum dalam Undang-Undang Dasar 1945, sebagaimana tertulis dalam Pasal 27 ayat (2): "Menjunjung tinggi hak asasi manusia serta menjamin segala warga Negara bersamaan kedudukannya di dalam hukum dan pemerintahan itu dengan tidak ada pengecualian". Berdasarkan ketentuan tersebut dapat disimpulkan bahwa Negara Republik Indonesia sangat menjunjung tinggi hukum dan hak asasi manusia serta persamaan warga negara dihadapan hukum seperti dalam hal seseorang warga Negara disangka melakukan perbuatan yang diduga sebagai tindak pidana, orang tersebut harus dilindungi dengan diperlakukan sebagai pihak yang belum bersalah sebelum adanya putusan yang telah mempunyai kekuatan hukum yang tetap yang menyatakan kesalahannya.

Warga negara adalah penduduk sebuah negara atau bangsa berdasarkan keturunan, tempat kelahiran, dan sebagainya, yang mempunyai kewajiban dan hak penuh sebagai warga negara itu, memiliki domisili atau tempat tinggal tetap di suatu wilayah negara, yang dapat dibedakan menjadi warga negara asli dan Warga Negara Asing (WNA). Berdasarkan UndangUndang Dasar 1945 Pasal 26 ayat (1) 
menyatakan bahwa : "Yang menjadi warga negara ialah orang-orang bangsa Indonesia asli dan orang-orang bangsa lain yang disahkan dengan undang-undang sebagai warga negara”. Pasal 26 ayat (2) : penduduk ialah warga negara Indonesia dan orang asing yang bertempat tinggal di Indonesia.

Orang asing yang akan masuk dan bertempat tinggal di Indonesia diatur dalam undang-undang mengenai masuk dan keluar wilayah Indonesia, dokumen perjalanan Republik Indonesia, visa, tanda masuk, dan izin tinggal, pengawasan keimigrasian, tindakan administratif keimigrasian, dan penyidikan. Perkembangan global dewasa ini mendorong meningkatnya mobilitas penduduk dunia yang menimbulkan berbagai dampak, baik yang menguntungkan maupun yang merugikan kepentingan dan kehidupan bangsa dan negara Indonesia, sehingga diperlukan peraturan perundang-undangan yang menjamin kepastian hukum keimigrasian yaitu Undang-Undang Nomor 6 Tahun 2011 Tentang Keimigrasian.

Untuk mengatur hal tersebut, di Indonesia telah di atur dalam peraturan perundang-undangan yang mengaturnya yaitu, Undang-undang Nomor 6 Tahun 2011 tentang Keimigrasian. Undang-Undang Keimgrasian merupakan peraturan yang mengatur hal ihwal lalu lintas orang yang masuk atau keluar wilayah Negara Republik Indonesia dan pengawasan terhadap orang asing di wilayah Negara Republik Indonesia. Orang asing yang akan masuk dan bertempat tinggal di Indonesia diatur dalam undang-undang mengenai masuk dan keluar wilayah Indonesia, dokumen perjalanan Republik Indonesia, visa, tanda masuk, dan izin tinggal, pengawasan keimigrasian, tindakan administratif keimigrasian, dan penyidikan.

Berdasarkan

Undang-undang

Keimigrasian orang asing dalam melakukan perjalanan di Indonesia wajib memiliki Dokumen Perjalan. Dokumen Perjalan adalah dokumen resmi yang dikeluarkan oleh pejabat yang berwenang dari suatu negara, Perserikatan Bangsa-Bangsa, atau organisasi internasional lainnya untuk melakukan perjalanan antar negara yang memuat identitas pemegangnya. Dokumen Perjalanan terdiri atas, Paspor dan Surat Perjalanan Laksana Paspor.

Semua aspek keimigrasian didasarkan pada apa yang telah digariskan dalam UndangUndang Dasar Negara Republik Indonesia Tahun 1945 sebagai hukum dasar untuk operasionalisasi dan pengaturan tugas-tugas pemerintahan di bidang keimigrasian. Di dalam dasar-dasar pertimbangan Undang-Undang Keimigrasian disebutkan antara lain, bahwa pengaturan dan pelayanan di bidang keimigrasian merupakan hak dan kedaulatan Negara Republik Indonesia sebagai Negara hukum berdasarkan Undang-Undang Dasar Negara Republik Indonesia Tahun 1945. Pengaturan keimigrasian ini tertuang dalam Undang-Undang Dasar Negara Republik Indonesia tahun 1945 Pasal 26 yang memuat Warga Negara dan penduduk, dimana Warga Negara dan penduduk adalah subjek dari pada keimigrasian itu sendiri.

Berkenaan dengan warga negara asing yang mencari suaka di atur dalam beberapa instrumen Internasional di antaranya ; (a) Deklarasi Universal Hak Asasi Manusia (DUHAM) 1948: Pasal 14 ayat 1 "setiap orang memiliki hak untuk mencari dan menikmati suaka di negara lain dari penuntutan". Pasal 15 ayat 1 "setiap orang memiliki hak atas kewarganegaraan". (b) Kovenan Internasional tentang Hak Sipil dan Politik (ICCPR): Pasal 12 ayat 1. "setiap orang yang secara sah berada dalam wilayah suatu negara harus, dalam wilayah negara tersebut, memiliki hak atas kebebasan bergerak dan kebebasan untuk memilih tempat tinggalnya". Pasal 12 ayat 2 "setiap orang harus bebas untuk meninggalkan negara manapun, termasuk sendiri".

Lebih lanjut dalam Undang-undang nasional juga menyebutkan hak setiap orang untuk mencari suaka yaitu pada Pasal 28 ayat (1) Undang-Undang Nomor 39 Tahun 1999 tentang Hak Asasi Manusia, "Setiap orang berhak mencari suaka untuk memperoleh perlindungan politik dari negara lain". Dari Undang-undang tersebut jelas bahwa Pemerintah Indonesia memiliki kewajiban untuk menerima para pencari suaka dengan segala konskuensi yang akan terjadi dengan penerimaan tersebut. Pemberian tempat tinggal atau izin tinggal sementara bagi para pencari suaka juga diberikan oleh Pemerintah Indonesia.

Di Indonesia terdapat dua organisasi Internasional sekaligus yang menangani masalah pengungsi, yaitu United Nations High Commissioner for Refugees (UNHCR) dan International Organization of Migration (IOM). Orang Asing yang menyatakan diri sebagai pengungsi atau pencari suaka, tidak dapat dikenakan sanksi seperti imigran ilegal. Namun, mereka akan diserahkan kepada pihak UNHCR dan IOM dalam penanganannya hingga 
penempatan ke negara ketiga. UNHCR merupakan salah satu badan kemanusiaan yang didirikan oleh PBB, dengan adanya badan kemanusiaan ini diharapkan para korban atas konflik yang terjadi di lingkungan mereka mendapatkan keamanan, dapat mencari suaka, mendapat tempat yang aman di wilayah lain ataupun di negara lain.

Satu-satunya aturan hukum yang digunakan oleh pemerintah Indonesia, khususnya pejabat imigrasi untuk mengatur soal pencari suaka dan pengungsi adalah, surat edaran IMI-1489.UM.08.05 yang dikeluarkan oleh Dirjen Imigrasi pada tahun 2010. Surat edaran tersebut mengatur bahwa setiap imigran yang mencari suaka tidak akan dideportasi; mereka akan dirujuk ke UNHCR dan diizinkan untuk tinggal (di Indonesia) selama mereka memiliki sertifikat pengungsi yang dikeluarkan oleh UNHCR. Mereka juga akan dibebaskan dari rumah detensi dengan persetujuan dari pejabat imigrasi, dan selanjutnya akan disupport oleh IOM atau UNHCR. Bagi mereka yang ditolak permohonannya (sebagai pengungsi) oleh UNHCR, akan dimasukkan ke rumah detensi, dikenakan denda, dan/atau dideportasi.

Menurut Pasal 1 Undang-Undang Keimigrasian, "Pengertian keimigrasian adalah hal ihwal lalu lintas orang yang masuk atau keluar Wilayah Indonesia serta pengawasanya dalam rangka menjaga tegaknya kedaulatan Negara". Ada dua hal yang sangat mendasar dalam hal pengertian keimigrasian Indonesia yaitu pertama adalah aspek lalu lintas orang antar negara, sedang yang kedua adalah menyangkut pengawasan orang asing yang meliputi pengawasan terhadap masuk dan keluar, pengawasan keberadaan serta pengawasan terhadap kegiatan orang asing di Indonesia.

Dalam penanganan pelanggaran keimigrasian dan untuk menampung para pencari suaka tersebut maka dibentuklah Rumah Detensi Imigrasi yang bertujuan untuk menangani pelanggaran prosedural keimigrasian yang dilakukan oleh warga negara asing termasuk para pencari suaka, dan juga melindungi hak asasi manusia dari warga negara asing sehingga dengan demikian maka dampak dari pelanggaran prosedural yang dilakukan oleh warga negara asing dapat di netralisir melalui Rumah Detensi Imigrasi sekaligus melindungi hak asasi manusia warga negara asing yang berada di wilayah Negara Republik Indonesia.
Jika terdapat warga negara asing melakukan pelanggaran secara yuridis mengenai keimigrasian tetapi para warga negara asing tersebut tidak dapat diperlakukan sewenangwenang oleh pemerintah negara Indonesia karena bagaimanapun juga warga negara asing memiliki hak asasi sebagai manusia yang sama dengan warga negara Indonesia. Warga negara asing yang berada di Rumah Detensi Imigrasi juga memiliki hak-hak yang wajib dilindungi dan dipenuhi. Hak-hak tersebut diantaranya hak atas jaminan kesehatan dan hak untuk mendapatkan makanan.

Hak atas kesehatan sebagai hak asasi manusia telah diakui dan ditur dalam berbagai instrumen internasional maupun nasional. Jaminan pengakuan hak atas kesehatan tersebut secara jelas dapat dilihat dari beberapa instrumen sebagai berikut:

Dalam instrumen Internasioanal diatur didalam (a) Universal Declaration of Human Right (UDHR), dalam pasal 25 "Setiap orang berhak atas taraf hidup yang menjamin kesehatan dan kesejahteraan untuk dirinya dan keluarganya, termasuk pangan, pakaian, perumahan dan perawatan kesehatannya serta pelayanan sosial yang diperlukan, dan berhak atas jaminan pada saat menganggur, menderita sakit, cacat, menjadi janda, mencapai usia lanjut atau mengalami kekurangan mata pencarian yang lain karena keadaan yang berada di luar kekuasaannya". (b) International Covenant on Economic, Social and Cultural Right (ICESCR, dalam Pasal 12 "Hak untuk menikmati standar kesehatan fisik dan mental yang tertinggi yang dapat dicapai”. (UDHCR dan ICESCR)

Dalam Pasal 25 menyebutkan bahwa Setiap orang berhak atas taraf hidup yang menjamin kesehatan dan kesejahteraan untuk dirinya dan keluarganya, termasuk pangan, pakaian, perumahan dan perawatan kesehatan. Dari pasal tersebut secara jelas menyebutkan bagaiman setiap orang berhak atas taraf hidup yang menjamin kesehatan dan kesejahteraan utntuk setiap orang. Lebih lanjut dalam Pasal 12 ayat (1) International Covenant on Economic, Social and Cultural Right (ICESCR) hak atas kesehatan dijelaskan sebagai "hak setiap orang untuk menikmati standar tertinggi yang dapat dicapai atas kesehatan fisik dan mental" tidak mencakup area pelayanan kesehatan (Afandi, 2008: 3). Hak atas kesehatan dapat diperoleh setiap manusia tak terkecuali oleh warga negara asing yang berada di setiap negara. 
Dalam instrumen Nasional diatur didalam (a) Undang-undang Dasar Negara Republik Indonesia Tahun 1945. Dalam pasal $28 \mathrm{H}$ ayat 1 "Setiap orang berhak hidup sejahtera lahir dan batin, bertempat tinggal, dan mendapatkan lingkungan hidup yang baik dan sehat serta berhak memperoleh pelayanan kesehatan. (b) Undang-undang Nomor 39 Tahun 1999 tentang Hak Asasi Manusia, dalam Pasal 9 ayat 3 "Setiap orang berhak atas lingkungan hidup yang baik dan sehat". (c) Undang-undang Nomor 36 tahun 2009 tentang Kesehatan. Dalam pasal 5. Ayat 1 "Setiap orang mempunyai hak yang sama dalam memperoleh akses atas sumber daya di bidang kesehatan".

Dalam pasal $28 \mathrm{H}$ ayat 1 Undang-undang Dasar Negara Republik Indonesia tahun1945 secara jelas menyebutkan bahwa Setiap orang berhak hidup sejahtera lahir dan batin, bertempat tinggal, dan mendapatkan lingkungan hidup yang baik dan sehat serta berhak memperoleh pelayanan kesehatan. Jadi dari pasal tersebut jelas menyebutkan semua orang tak terkecuali warga negara asing yang berada di wilayah indonesia berhak mendapatkan pelayanan kesehatan.

Dalam Peraturan Direktur Jendral Imigrasi Nomor IMI.1917-OT.02.10 Tahun 2013 Tentang Standar Operasional Prosedur Rumah Detensi Imigrasi. Bagian V Pelaksanaan point 2 Pelayanan deteni bagian $\mathrm{c}$ kesehatan dan kebersihan mengatur tentang seksi perawatan dan kesehatan bertugas mengupayakan kesehatan dan kebersihan dengan melakukan pemeriksaan kesehatan deteni secara rutin, dalam hal kondisi kesehatan Deteni tidak dapat ditangani petugas kesehatan rudenim, pemeriksaan kesehatan Deteni dapat dilkukan di klinik, puskesmas, atau rumah sakit untuk mendapatkan penanganan lebih lanjut.

Berkenaan dengan kesehatan Deteni suda di atur secara jelas dalam Peraturan Direktur Jendral Imigrasi Nomor IMI.1917OT.02.01 Tahun 2013 Tentang Standar Operasional Prosedur Rumah Detensi Imigrasi, yang mengatur bagai mana pelayanan Deteni yang diberikan secara rutin, berkala dan berkesinambungan kepada Deteni yang berada di Rumah Detensi Imigrasi

Hak untuk mendapatkan makanan diakui oleh dunia internasional dalam sejumlah konvensi dan deklarasi diantaranya (a) Universal Declaration of Human Right (UDHR), dalam pasal 25 ayat 1 "Setiap orang berhak atas taraf hidup yang menjamin kesehatan dan kesejahteraan untuk dirinya dan keluarganya, termasuk pangan, pakaian, perumahan dan perawatan kesehatannya serta pelayanan sosial". (b) Kovenan Internasional tentang Hak-hak Ekonomi, Sosial, dan Budaya (International Covenant on Economic, Social and Cultural Rights), Pasal 11 Ayat 1. "Negara-negara Peserta pada Kovenan yang sekarang ini mengakui hak setiap orang atas standar kehidupan yang layak untuk dirinya dan keluarganya, termasuk makanan, pakaian, dan tempat tinggal yang layak, dan peningkatan kondisi hidup yang berkesinambungan". Pasal 11 ayat 2. "Negara-negara Peserta pada Kovenan yang sekarang ini mengakui hak asasi setiap orang untuk bebas dari rasa lapar, baik secara individual maupun kerja sama internasional, harus melakukan pengukuran, termasuk di dalamnya adalah program-program khusus, yang dibutuhkan" (c) Deklarasi Konferensi Pangan Sedunia (World Food Conference Declaration) pada tahun 1974, menyatakan, "Setiap pria, perempuan, dan anak, memiliki hak yang tidak dapat dicabut untuk bebas dari rasa lapar dan malnutrisi".

Berdasarkan deklarasi dan konvensi tersebut, maka merupakan kewajiban bagi negara-negara anggota PBB untuk membuat suatu perundang-undangan yang menjamin hak atas pangan bagi setiap rakyatnya. Dan sebagai negara peserta $\mathrm{PBB}$, tentunya Indonesia terikat terhadap sejumlah deklarasi dan konvensi tersebut di atas. Apalagi Indoensia juga telah meratifikasi Kovenan Internasional tentang Hak Ekonomi, Sosial, dan Budaya pada bulan September 2005.

Hak untuk mendapatkan makanan juga di atur secara jelas di Indonesia dalam Undangundang Nomor 18 Tahun 2012 Tentang Pangan pasal 3 "Penyelenggaraan Pangan dilakukan untuk memenuhi kebutuhan dasar manusia yang memberikan manfaat secara adil, merata, dan berkelanjutan berdasarkan Kedaulatan Pangan, Kemandirian Pangan, dan Ketahanan Pangan”.

Dalam Peraturan Direktur Jendral Imigrasi Nomor IMI.1917-OT.02.01 Tahun 2013 Tentang Standar Operasional Prosedur Rumah Detensi Imigrasi. Pasal 4 Bagian V Pelaksanaan point 2 Pelayanan deteni bagian (b) penyediaan kebutuhan makanan dan minuman mengatur tentang penyediaan makanan dan minuman yang layak sebanyak tiga kali dalam sehari, makanan tambahan untuk kesehatan atau daya tahan tubuh Deteni, peraturan pemberian makanan, seperti cara pembagian, jadwal makan 
bagi Deteni yang menjalankan ibadah keagamaan, seperti puasa, disesuaikan dengan waktu sahur dan berbuka serta pemberian jenis makanan dan minuman tertentu bagi deteni berdasarkan rekomendasi petugas kesehatan.

Berkenaan dengan hak untuk makanan Deteni suda di atur secara jelas dalam Peraturan Direktur Jendral Imigrasi Nomor IMI.1917OT.02.01 Tahun 2013 Tentang Standar Operasional Prosedur Rumah Detensi Imigrasi, yang mengatur bagai mana pelayanan Deteni yang diberikan makanan tiga kali dalam sehari, selama berstatus Deteni yang berada di Rumah Detensi Imigrasi

Pada dasarnya setiap Deteni berhak untuk mendapatkan pelayanan kesehatan dan berhak untuk mendapatkan makanan yang layak dan petugas Rumah Detensi Imigrasi berkewajiban untuk memberikan jaminan kesehatan dan memberikan makanan yang layak bagi Deteni.

Namun kenyataannya, Pelayanan kesehatan dan makanan yang diterima oleh Deteni belum sesuai dengan standar operasional prosedur yang diatur dalam Peraturan Direktur Jendral Imigrasi Nomor IMI.1917-OT.02.01 Tahun 2013. Hasil Observasi yang telah dilakukan tanggal 12 Januari 2019 di Rumah Detensi Imigrasi Makassar, pelayanan kesehatan belum dilakukan secara rutin menurut standar operasional prosedur data di lihat dari laporan Kasubsi perawatan dan kesehatan. Sedangkan pelayanan makanan belum terpenuhi secara sempurna, karena setiap Deteni yang seharusnya mendapatkan jatah makanan yang layak tiga kali dalam sehari. Menurut pengamatan penulis makanan yang diberikan masih jauh dari kata layak yaitu Empat sehat Lima sempurna. Makanan yang diberikan juga kadang tidak sesuai dengan peraturan yang ditetapkan.

\section{METODE PENELITIAN}

Penelitian ini termasuk jenis penelitian deskriptif kualitatif yaitu menggambarkan hasil penelitian dengan mendeskripsikan data aktual yang diperoleh dalam proses penelitian. Penelitian ini bersifat deskriptif kualitatif yang bermaksud untuk mendeskripsikan pemenuhan hak mendapatkan pelayanan kesehatan dan hak mendapatkan makanan bagi Deteni di Rumah Detensi Imigrasi Makassar. Penelitian deskriptif kualitatif diuraikan dengan kata-kata menurut pendapat responden, apa adanya sesuai dengan pertanyaan penelitiannya, kemudian dianalisis pula dengan kata-kata apa yang melatar belakangi responden berprilaku berpikir, berperasaan, dan bertindak. (Husaini Usman \& Purnomo Setiady, 2011:130)

Pendekatan yang digunakan dalam penelitian ini adalah pendekatan kualitatif, yaitu prosedur penelitian yang menghasilkan data deskriptif berupa kata-kata yang berbentuk tulisan dan lisan yang diperoleh dari sumber data/informan. Penggunaan pendekatan kualitatif didasarkan atas pertimbangan bahwa pendekatan ini menyajikan data secara langsung antara peneliti dan informan dalam mengungkap dan mengkaji dengan cara mendalami masalah yang menjadi variable penelitian, yaitu pemenuhan hak mendapatkan pelayanan kesehatan dan hak mendapatkan makanan bagi Deteni di Rumah Detensi Imigrasi Makassar.

Fokus penelitian merupakan pokok permaslahan yang menjadi pusat perhatian dalam penelitian. Adapun fokus dari penelitian ini adalah pemenuhan hak mendapatkan pelayanan kesehatan dan makanan bagi Deteni di Rumah Detensi Imigrasi Makassar.

Untuk memperoleh persamaan persepsi dalam penelitian ini, maka dipandang perlu memberikan deskripsi yang perlu diteliti, yakni pemenuhan hak mendapatkan pelayanan kesehatan dan hak mendapatkan makanan bagi Deteni di Rumah Detensi Imigrasi Makassar. Untuk memudahkan pengamatan dikonseptualisasikan fokus penelitian, maka fokus tersebut perlu di deskripsikan secara kongkrit, spesifik dan operasional sbb:

Pengatur hukum yang dimaksud yaitu pengaturan hukum hak mendapatkan pelayanan kesehatan dan hak mendapatkan makanan bagi Deteni di Rumah Detensi Imigrasi Makassar.

Pemenuhan hak mendapatkan pelayanan kesehatan yang dimaksud dalam penelitan ini yaitu Pemeriksaan Kesehatan secara rutin.

Pemenuhan hak mendapatkan makanan yang dimaksud dalam penelitan ini yaitu penyediaan makanan yang layak sebanyak tiga kali sehari.

Deteni yang dimaksud dalam penelitian ini ialah Orang Asing yang dikenai tindakan administratif keimigrasian.

Adapun jenis dan sumber data dalam penelitian ini adalah sebagai berikut:

Data primer adalah data yang diperoleh atau dikumpulkan langsung dilapangan mengenai variabel yang diteliti. Data sekunder merupakan data yang diperoleh melalui studi 
kepustakaan sebagai data pendukung yang terdiri dari buku-buku, laporan dari hasil penelitian, jurnal ilmiah, dan sumber lainnya yang berkaitan dengan permasalahan yang diteliti.

Sumber data primer diperoleh dari hasil wawancara terhadap pegawai Rudenim dan Deteni di Rumah Detensi Imigrasi Makassar. Sumber data sekunder. Studi pustaka (Library Research). Studi ini dilaksanakan untuk mengumpulkan sejumlah data, meliputi bahan pustaka yang bersumber dari buku-buku, media massa dan media cetak lainnya yang berhubungan dengan permasalahan yang diteliti.

Dalam penelitian ini, yang menjadi instrumen penelitian adalah peneliti itu sendiri karena manusialah yang dapat memahami makna interaksi antar manusia, membaca gerak muka, atau menyelami perasaan dan nilai yang terkandung dalam ucapan atau perbuatan responden, untuk itu dibutuhkan beberapa instrumen pendukung seperti tape recorder, kamera dan buku catatan serta pedoman wawancara. Peneliti juga menjadi instrumen kunci yang berfungsi menetapkan fokus, memilih informan sebagai sumber data, melakukan pengumpulan data, menilai kualitas data, menganalisis data, menafsirkan data dan membuat kesimpulan atas temuannya.

Teknik pengumpulan data yang digunakan peneliti dalam penelitian ini adalah:

Wawancara adalah percakapan dengan maksud tertentu yang dilakukan oleh dua pihak, yaitu pewawancara yang mengajukan pertanyaan dan terwawancara yang memberikan jawaban atas pertanyaan.Wawancara dalam penelitian ini dilakukan kepada petugas Rumah Detensi Imigrasi dan deteni. Wawancara dimaksudkan untuk memperoleh data-data yang terjadi dilapangan dengan pihak-pihak yang telah disebutkan..

DokumentasiTeknik dokumentasi yang dilakukan oleh peneliti yaitu berupa dokumentasi dalam bentuk dokumen/data, foto, rekaman, maupun catatan hasil wawancara pada saat melakukan penelitian dengan pihak-pihak yang terkait.

Data yang diperoleh, baik data primer maupun sekunder dianalisis dengan teknik kualitatif disajikan secara deskriptif.Seluruh data yang diperoleh dari wawancara dan dokumentasi, peneliti mendeskripsikan, menganalisis, menginterpretasikan, memaparkan dan membandingkan kembali dengan mencocokkan teori yang ada hubungannya dengan penelitian ini sehingga terjadi hubungan yang signifikan antara prediksi secara teoritis.

Analisis data terdiri dari tiga alur kegiatan, yaitu sebagai berikut:

1. Reduksi data yang dilakukan peneliti yaitu, pemusatan perhatian pada penyederhanaan, pengabstrakan dan transformasi data. Reduksi data berlangsung secara terus menerus selama pengumpulan data berlangsung.

2. Penyajian data yang dilakukan peneliti, sekumpulan informasi tersusun dengan melakukan penarikan kesimpulan dan pengambilan tindakan.

3. Menarik kesimpulan dan verifikasi yang dilakukan peneliti yaitu akhir dari pengumpulan data. Setelah menyajikan data peneliti akan menarik kesimpulan dan menjawab rumusan masalah berdasarkan apa yang diperoleh dilapangan secara keseluruhan, melakukan penyimpulan akhir dan mendeskripsikannya sebagai hasil penelitian. Penarikan kesimpulan yang dilakukan peneliti merupakan pembuktian kembali atau verifikasi dapat dilakukan untuk mencari pembenaran dan persetujuan, sehingga validasi tercapai.

Keabsahan data dimaksudkan untuk memperoleh tingkat kepercayaan yang berkaita dengan seberapa jauh kebenaran hasil penelitian.Untuk mendapatkan keabsahan data, peneliti melakukan teknik pemeriksaan dan keabsahan data dengan uji krebilitas.

1. Perpanjanagan pengamatanPerpanjangan pengamatan dilakukan karena data yang ditemukan sebelumnya belum lengkap.

2. Meningkatkan ketekunanTeknik ketekunan pengamatan yang dilakukan peneliti yaitu mengadakan pengamatan dengan teliti, rinci, dan mendalam serta berkesinambungan terhadap fenomena dan peristiwa yang terjadi pada latar penelitian.

3. TriangulasiTeknik triangulasi yang dilakukan oleh peneliti yaitu mengecekulang derajat keterpercayaan data atau informasi yang telah diperoleh.Triangulasi yang dilakukan adalah triangulasi sumberdengan menggali kebenaran informasi tertentu melalui berbagai metode dan sumber perolehan data.

\section{HASIL DAN PEMBAHASAN}

Lokasi yang digunakan untuk penelitian adalah Rumah Detensi Imigrasi Makassar, Alamat: J1. Lembaga Bollangi, Desa Timbuseng, Kecamatan Pattallassang, Kabupaten Gowa, Provinsi Sulawesi Selatan. 


\section{Sejarah Berdirinya Rumah Detensi Imigrasi Makassar \\ Pada tahun 1992 berdasarkan Undang-} undang Nomor 9 Thun 1992 Tentang Keimigrasian Pasal 1 angka 15 disebutkan bahwa karantina imigrasi adalah tempat penampungan sementara bagi orang asing yang dikenakan proses pengusiran atau deportasi atau penindakan keimigrasian lainya. Berdasarkan Undang-Undang tersebut maka dikenallah istilah Karantina Imigrasi sebagai bentuk permulaan dan rudenim.

Pada Maret 2004, Berdasarkan keputusan Menteri Kehakiman dan HAM RI Nomor M.01.PR.07.04 tahun 2004 tentang Organisasi dan Tata Kerja Rumah Detensi Imigrasi, maka sejak saat itulah istilah Karantina Imigrasi berubah menjadi RUDENIM. Kedatangan dan keberadaan migran di wilayah Indonesia yang cenderung meningkat, berpotensi menimbulkan berbagai permasalahan keimigrasian sehingga diperlukan upaya penindakan menurut ketentuan keimigrasian.

Untuk lebih mengefektifkan dan mengefisiensikan pelaksanaan tugas di bidang penindakan keimigrasian diperlukan sarana dan prasarana pendukung berupa Rumah Detensi Imigrasi. Rumah Detensi Imigrasi disingkat RUDENIM adalah unit pelaksana teknis yang menjalankan Fungsi Keimigrasian sebagai tempat penampungan sementara bagi orang asing yang melanggar Undang-Undang Imigrasi. Orang asing yang tinggal di rudenim disebut dengan deteni. Rudenim dibangun karena meningkatnya lalu lintas orang asing, baik yang keluar maupun yang masuk ke wilayah Indonesia. Sehingga berpotensi timbulnya permasalahan keimigrasian terhadap kedatangan dan keberadaan orang asing di indonesia yang memerlukan upayah penindakan bagi orang asing yang melanggar ketentuan yang berlaku.

Berdasarkan hal tersebut di atas, dibentuklah tiga belas Rumah Detensi Imigrasi di Indonesia yang tersebar di berbagai kota yaitu Jakarta, Medan, Pekanbaru, Batam, Semarang, Surabaya, Pontianak, Balikpapan, Manado, Denpasar, Kupang, Jayapura. dan Makassar. Rumah Detensi Imigrasi Makassar termasuk salah satu diantaranya Rumah Detensi Imigrasi yang ada di Indonesia dengan Keputusan Menteri Kehakiman dan Hak Asasi Manusia RI Nomor : M.01.PR.07.04 Tahun 2004 tanggal 9 Maret 2004 tentang Organisasi dan Tata Kerja Rumah Detensi. Rumah Detensi Imigrasi
Makassar di resmikan oleh Menteri Hukum dan Hak Asasi Manusia RI Hamid Awaluddin pada tanggal 26 Januari 2015.

\section{Visi dan Misi Rumah Detensi Imigrasi Makassar}

Adapun visi dan misi dalam melaksanakan kegiatan di Rumah Detensi Imigrasi Makassar sebagai berikut:

Visi Rumah Detensi Imigrasi Makassar tidak terlepas dari Visi Kementerian Hukum dan Hak Asasi Manusia Republik Indonesia yaitu "Masyarakat memperoleh kepastian hukum".

Misi Rumah Detensi Imigrasi Makassar juga tidak terlepas dari Misi Kementerian Hukum dan Hak Asasi Manusia Republik Indonesia yaitu "Melindungi Hak-hak Asasi Manusia".

\section{Kedudukan, Tugas dan Fungsi Rumah Detensi Imigrasi Makassar}

Kedudukan Rumah Detensi Imigrasi Makassar. Rumah Detensi Imigrasi Makassar (Rudenim) adalah Unit Pelaksana Teknis dibidang keimigrasian di lingkungan Kementerian Hukum dan Hak Asasi Manusia Republik Indonesia yang berada dibawah dan bertanggung jawab kepada Kantor Wilayah Kementerian Hukum dan Hak Asasi Manusia Republik Indonesia.

Tugas Rumah Detensi Imigrasi Makassar. Rumah Detensi Imigrasi Makassar mempunyai tugas melaksanakan sebagian tugas pokok Kementerian Hukum dan Hak Asasi Manusia Republik Indonesia di bidang Pendetensian orang asing.

Fungsi Rumah Detensi Imigrasi Makassar. Rudenim mempunyai fungsi menurut Keputusan Menteri Kehakiman dan HAM Republik Indonesia Nomor M.01-PR.07.04 Tahun 2004 tentang Organisasi dan Tata Cara Kerja Rumah Detensi Imigrasi, yaitu: 1) melaksanakan tugas penindakan; 2) melaksanakan tugas pengisolasian; 3) melaksanakan tugas pemulangan dan pengusiran/deportasi.

Fungsi Rumah Detensi Imigrasi tersebut merupakan penjabaran dari misi Kementrian Hukum dan HAM, yaitu melindungi Hak Asasi Manusia, penegakan hukum meningkatnya upaya perlindungan, pemajuan, penegakan, pemenuhan dan penghormatan HAM.

\section{Hasil}


Data yang dikumpulkan dalam penelitian ini melalui wawancara observasi dan dokumentasi. Data yang tidak terungkap melalui wawancara dilengkapi dengan data hasil observasi langsung yang dilakukan dalam rentang waktu dari Maret sampai dengan April. Untuk memperkuat substansi data hasil wawancara, dan observasi, maka dilakukan penelusuran terhadap dokumen dan arsip yang ada. Semua data hasil penelitian ini diuaraikan berdasarkan pada fokus penelitian yaitu sebagai berikut:

\section{Pengaturan Hukum Warga Negara Asing (Deteni)}

Warga negara asing merupakan seseorang yang tinggal dan menetap di sebuah negara tertentu namun bukan berasal dari negara tersebut juga tidak secara resmi terdaftar sebagai warga negara, yang memiliki tujuan yang beragam, misalnya dalam rangka menempuh pendidikan, bisnis maupun hal lainnya. Meskipun status seseorang tersebut adalah warga negara asing di Indonesia, seseorang tersebut tetap memiliki hak dan juga kewajiban terhadap negara yang di tinggalinya.

Warga negara asing, berdasarkan Pasal 26 ayat (2) Undang - Undang Dasar 1945 menyatakan: "Penduduk ialah warga negara Indonesia dan orang asing yang bertempat tinggal di Indonesia".

Istilah kewarganegaraan memiliki arti keanggotaan yang menunjukkan hubungan atau ikatan antara negara dan warga negara. Kewarganegaraan di artikan segala jenis hubungan dengan suatu negara yang mengakibatkan adanya kewajiban negara itu untuk melindungi orang yang bersangkutan. Adapun menurut Undang - undang kewarganegaraan Republik Indonesia, kewarganegaaran adalah segala ikhwal yang berhubungan dengan negara.

Pengertian kewarganegaraan di bedakan menjadi dua, yaitu sebagai berikut: Kewarganegaraan dalam arti yuridis dan sosioligis. Kewarganegaraan dalam arti yuridis ditandai dengan adanya ikatan hukum antara orang - orang dengan negara. Kewarganegaraan dalam arti sisiologis tidak ditandai dengan ikatan hukum, tetapi ikatan emosional, seperti ikatan perasaan, ikatan keturunan, ikatan nasib, ikatan sejarah dan ikatan tanah air.

Kewarganegaraan dalam arti formil dan materil. Kewarganegaraan dalam arti formil menunjukkan pada tempat kewarganegaraan. Dalam sistematika hukum, masalah kewarganegaraan berada pada hukum publik. Kewarganegaraan dalam arti materil menunjukkan pada akibat hukum dari status kewarganegaraan, yaitu adanya hak dan kewajiban negara. Kewarganegaraan Republik Indonesia diatur dalam Undang -Undang Nomor 12 Tahun 2006 Tentang Kewarganegaraan Republik Indonesia.

Warga negara asing, berdasarkan Undang-Undang Nomor 12 Tahun 2006 tentang Kewarganegaraan Republik Indonesia pasal 1 (1) menyatakan : "Warga negara adalah warga suatu negara yang ditetapkan berdasarkan peraturan perundang-undangan".

Warga negara asing, berdasarkan Pasal 1 (9) Undang - Undang Nomor 6 Tahun 2011 tentang Keimigrasian : "Orang asing adalah orang yang bukan warga Indonesia".

Dari hasil analisis Pengaturan Hukum Warga Negara Asing (Deteni) tentang pelayanan kesehatan dan makanan di atur dalam Peraturan Direktur Jendral Imigrasi Nomor IMI.1917OT.02.01 Tahun 2013 Tentang Standar Operasional Prosedur Rumah Detensi Imigrasi. Pelayanan kesehatan diatur pada Bagian V Pelaksanaan point 2 Pelayanan deteni bagian (c) Pelayanan kesehatan dan kebersihan bertugas mengupayakan Kesehatan dan kebersihan dengan melakukan; 1) pemeriksaan kesehatan Deteni secara rutin; 2) dalam hal kondisi kesehatan Deteni tidak dapat ditangani oleh petugas kesehatan rudenim, pemeriksaan kesehatan Deteni dapat dilakukan di klinik, puskesmas, atau rumah sakit untuk mendapatkan penanganan lebih lanjut; 3) bagi Deteni dalam kondisi kesehatan kritis, dapat diberikan fasilitas pemeriksaan kesehatan di Unit Gawat Darurat (UGD) rumah sakit; 4) Deteni yang mengidap penyakit akut, dapat dirawat di rumah sakit; 5) fasilitas sebagaimana dimaksud pada angka dua sampai dengan angka empat harus mendapatkan izin dari Kepala Rudenim; 6) setiap tempat, blok, atau ruangan di Rudenim dilakukan perawatan kebersihan untuk pencegahan penularan penyakit, seperti pengasapan (foging) untuk mencegah berkembangnya penyakit demam berdarah, penyebaran kutu, atau serangga; 7) menyiapkan peralatan mandi, mencuci dan kebersihan ruangan.

Pelayanan makanan juga di atur dalam Peraturan Direktur Jendral Imigrasi Nomor IMI.1917-OT.02.01 Tahun 2013 Tentang 
Standar Operasional Prosedur Rumah Detensi Imigrasi. Bagian $\mathrm{V}$ Pelaksanaan point 2 Pelayanan deteni bagian (b) penyediaan kebutuhan makanan dan minuman mengatur tentang penyediaan 1) makanan dan minuman yang layak sebanyak tiga kali dalam sehari: 2) makanan tambahan untuk kesehatan atau daya tahan tubuh Deteni: 3) peraturan pemberian makanan, seperti cara pembagian, jadwal makan bagi Deteni yang menjalankan ibadah keagamaan, seperti puasa, disesuaikan dengan waktu sahur dan berbuka: 4) pemberian jenis makanan dan minuman tertentu bagi deteni berdasarkan rekomendasi petugas kesehatan: 5) Pemberian makanan dan minuman bagi Deteni baru yang datang untuk ditempatkan di Rudenim diluar jam makan,berdasarkan rekomendasi Kepala Rudenim.

\section{Pemenuhan Hak Mendapatkan Pelayanan Kesehatan dan Makanan Deteni di Rumah Detensi Imigrasi Makassar}

\section{a. Pemenuhan Hak Mendapatkan Pelayanan Kesehatan Deteni di Rumah Detensi Imigrasi Makassar}

Kesehatan adalah keadaaan sejahtera dari badan, jiwa dan sosial yang memungkinkan setiap orang hidup produktif secara sosial dan ekonomi. Karena itu kesehatan merupakan dasar dari diakuinya derajat kemanusiaan. Tanpa kesehatan, seseorang menjadi tidak sederajat secara kondisional. Tanpa kesehatan, seseorang tidak akan mampu memperoleh hak-hak lainnya. Sehingga kesehatan menjadi salah satu ukuran selain tingkat pendidikan dan ekonomi, yang menentukan mutu dari sumber daya manusia.

Dalam Pasal 1 Undang-Undang Republik Indonesia Nomor 36 tahun 2009 tentang kesehatan memberikan penjelasan, yang dimaksud dengan kesehatan adalah keadaan sehat, baik secara mental, fisik, spiritual maupun sosial yang memungkinkan setiap orang untuk hidup produktif secara sosial dan ekonomi. Kesehatan juga merupakan hak asasi manusia dan salah satu unsur kesejahteraan yang harus diwujudkan sesuai dengan cita-cita bangsa Indonesia sebagaimana dimaksud dalam Pancasila dan Undang-Undang Dasar Negara Republik Indonesia Tahun 1945.

Berdasarkan hasil analisi pada pemeriksaan bulan April 2018 terdapat satu orang yang terindikasi menderita penyakit kulit yang kemudian diberikan tindak lanjut berupa rujukan ke puskesmas terdekat atas nama Qasim Ali Afsali warga negara Afghanistan. Pada bulan Oktober 2018 terdapat satu orang dirujuk ke puskesmas karna demam atas nama Omar Salaa Mubarak umur 29 tahun warga negara Somalia. Dan pada bulan Februari 2019 terdapat satu orang dirujuk ke puskesmas Pattalassang yang terindikasi gejala demam berdarah atas nama Zaid Mohamed Adam Abdelrahman umur 39 tahun warga negara Sudan.

\section{b. Pemenuhan Hak Mendapatkan Makanan bagi Deteni di Rumah Detensi Imigrasi Makassar}

Makanan diperlukan untuk kehidupan karena makanan merupakan salah satu kebutuhan pokok bagi kehidupan manusia. Makan berfungsi untuk memelihara proses tubuh dalam proses pertumbuhan atau perkembangan serta mengganti jaringan tubuh yang rusak, memperoleh energi untuk melakukan aktifitas sehari-hari, mengatur metabolisme dan berbagai keseimbangan air, mineral, dan cairan tubuh yang lain, juga berperan di dalam mekanisme pertahanan tubuh terhadap berbagai penyakit.

Setiap Manusia Membutuhkan makanan, hal juga trkait dengan UndangUndang No. 39 Tentang Hak Asasi Manusia bahwa setiap manusia melanjutkan hidupnya, begitu juga bagi para Deteni yang berada di Rumah Detensi Imigrasi Makassar, Mereka juga berhak mendapatkan makanan yang layak, bergizi untuk memenuhi kebutuhan kalorinya.

Hak untuk mendapatkan makanan juga di atur secara jelas di Indonesia dalam Undangundang Nomor 18 Tahun 2012 Tentang Pangan pasal 3 "Penyelenggaraan Pangan dilakukan untuk memenuhi kebutuhan dasar manusia yang memberikan manfaat secara adil, merata, dan berkelanjutan berdasarkan Kedaulatan Pangan, Kemandirian Pangan, dan Ketahanan Pangan".

Dalam Peraturan Direktur Jendral Imigrasi Nomor IMI.1917-OT.02.01 Tahun 2013 Tentang Standar Operasional Prosedur Rumah Detensi Imigrasi. Bagian V Pelaksanaan point 2 Pelayanan deteni bagian (b) penyediaan kebutuhan makanan dan minuman mengatur tentang penyediaan makanan dan minuman yang layak sebanyak tiga kali dalam sehari, makanan tambahan untuk kesehatan atau daya tahan tubuh Deteni, peraturan pemberian makanan, seperti cara pembagian, jadwal makan bagi Deteni yang menjalankan ibadah keagamaan, 
seperti puasa, disesuaikan dengan waktu sahur dan berbuka serta pemberian jenis makanan dan minuman tertentu bagi deteni berdasarkan rekomendasi petugas kesehatan.

Dari aturan tersebut di atas bahwa jelas aturan yang mengatur tentang pelayanan makanan bagi Deteni di atur di dalam Peraturan Direktur Jendral Imigrasi Nomor IMI.1917OT.02.01 Tahun 2013 Tentang Standar Operasional Prosedur Rumah Detensi Imigrasi. Bagian V Pelaksanaan point 2 Pelayanan deteni bagian (b) penyediaan kebutuhan makanan dan minuman. Dalam aturan tersebut secara jelas mengatakan petugas Rumah Detensi Imigrasi bertugas menyediakan makanan dan minuman yang layak sebanyak tiga kali dalam sehari.

\section{Faktor yang Mempengaruhi dalam} Pemenuhan Hak Mendapatkan Pelayanan Kesehatan dan Makanan bagi Deteni Di Rumah Detensi Imigrasi Makassar

Hak mendapatkan pelayanan kesehatan dan makanan yang layak merupakan hak bagi Deteni yang harus dipenuhi oleh pihak Rumah Detensi Imigrasi Makassar. Pelaksanaan pemenuhan hak mendapatkan pelayanan kesehatan dan makanan bagi Deteni, tentu saja pihak Rumah Detensi Imigrasi Makassar Masi terdapat faktor-faktor yang mempengaruhi yang disebabkan beberapa faktor baik dalam pemenuhan hak mendapatkan pelayanan kesehatan dan makanan yang layak bagi Deteni diantaranya :

\section{a. Faktor Pendukung dalam Pemenuhan Hak Mendapatkan Pelayanan Kesehatan dan Makanan bagi Deteni Di Rumah Detensi Imigrasi Makassar}

Beberapa faktor pendukung dalam Pemenuhan Hak Mendapatkan Pelayanan Kesehatan dan Makanan bagi Deteni Di Rumah Detensi Imigrasi Makassar diantaranya: Pegawai Rumah Detensi Imigrasi Makassar yang memadai

Sumber daya manusia pada dasarnya adalah merupakan salah satu faktor yang sangat penting didalam suatu organisasi publik maupun swasta, karena manusia yang merencanakan sampai mengawasi pelaksanaan kegiatan dalam organisasi. Begitupun dengan pegawai Rumah Detensi Imigrasi merupakan faktor penentu dalam pelaksanaan peran dalam memberikan pelayanan kesehatan dan makanan.
Keberhasilan suatu instansi akan berhasil dalam melaksanakan pelayanan yang baik sesuai dengan tugas dan fungsi jika didukung dengan Jumlah pegawai yang memadai. Pegawai Rumah Detensi Imigrasi Makassar haruslah cukup jumlahnya sesuai dengan kebutuhan serta memiliki keterampilan yang memadai sesuai dengan ketentuan tugastugas, dan fungsi Rumah Detensi Imigrasi Makassar.

Berdasarkan hasil wawancara tersebut dapat disimpulkan bahwa pegawai yang memadai merupakan faktor yang menjadi pendukung terlaksananya pemenuhan hak mendapatkan pelayanan kesehatan dan makanan yang layak bagi Deteni di Rumah Detensi Imigrasi Makassar. Jumlah pegawai saat ini yang berstatus pegawai negeri sipil di Rumah Detensi Imigrasi makassar berjumlah 52 orang pegawai terdiri dari 13 orang pegawai perempuan dan 39 pegawai laki-laki. Dengan cukupnya jumlah pegawai di rumah Detensi Imigrasi Makassar maka hal tersebut menjadi faktor pendukung dalam pemenuhan hak pelayanan kesehatan dan makanan bagi deteni di Rumah Detensi Imigrasi Makassar.

\section{b. Faktor Penghambat dalam Pemenuhan Hak Mendapatkan Pelayanan Kesehatan dan Makanan bagi Deteni Di Rumah Detensi Imigrasi Makassar}

Beberapa faktor penghambat dalam Pemenuhan Hak Mendapatkan Pelayanan Kesehatan dan Makanan bagi Deteni Di Rumah Detensi Imigrasi Makassar diantaranya:

1) Anggran Yang Terbatas

Berjalannya suatu aktifitas pelayanan perlu adanya suatu anggaran yang tersistematis dan terpadu sebagai acuan dalam pelayanan. Anggaran merupakan salah satu faktor yang sangat mempengaruhi Rumah Detensi Imigrasi Makassar dalam pelaksanaan pemberian pelayanan kesehatan dan makanan.

2) Keterbatasan Sarana dan Prasarana

Faktor penghambat selanjutnya adalah sarana dan prasarana dalam pemenuhan hak mendapatkan pelayanan kesehatan dan makanan di Rumah Detensi Imigrasi Makassar,

Sarana dan prasarana kesehatan di rumah detensi Imigrasi Makassar belum terlalu lengkap sehingga menjadi penghambat dalam pelayanan awal terhadap kesehatan. dibuktikan bahwa timbangan yang seharusnya sebagai alat dasar dalam melakukan pemeriksaan kesehatan 
justru tidak ada. Selain itu alat dasar Tensimeter yang digunakan sebagai alat untuk mengecek tekanan darah sebelum dilakukan diagnosa lebih lanjut kepada pasien. Serta alat kesehatan dasar lainnya yaitu termometer yang digunakan sebagai pengukur suhu tubuh padahal termometer sangat bermanfaat untuk mengukur dan memantau suhu tubuh dengan cepat dan tepat sehingga bisa untuk mengantisipasi apakah perlu segera dibawa ke dokter atau hanya cukup diberi obat penurun demam.

Sarana dan prasarana dapur di rumah detensi Imigrasi Makassar belum terlalu lengkap sehingga menjadi penghambat dalam pelayanan awal terhadap pemenuhan hak mendapatkan makanan yang layak. Dibuktikan alat dapur yang menjaga nasi tetap hangat yaitu Rice Cooker tidak ada pasilitas tersebut, Tempat penyimpanan beras agar beras terjaga kualitasnya juga tidak disediakan oleh pegawai Rumah Detensi Imigrasi Makassar, Dispenser yang digunakan tempat penyimpanan air juga tidak disediakan, Blender yang digunakan sebagai alat untuk menghaluskan rempa-rempa agar rasa masakan lebih berkualitas juga tidak ada dalam sarana dan prasarana alat dapur, dan yang palling penting kulkas yang seharusnya disediakan karna Deteni hanya disediakan bahan-bahan makanan yang seharusnya disimpan kedalam kulkas agar kualitas bahanbahan makanan tersebut terjaga kalitasnya.

Dari hasil analisis yang dilakukan bahwa keadaan sarana dan prasarana pelayanan kesehatan dan makanan belum terpenuhi dengan lengkap sehingga menjadi penghambat dalam pemenuhan hak mendapatkan pelayanan kesehatan dan makanan. Semestinya hal tersebut terpenuhi secara maksimal agar pelaksanaan pelayanan kesehatan dan makanan dapat terpenuhi dengan baik.

\section{Pembahasan}

\section{Pengaturan Hukum Warga Negara Asing (Deteni) di Rumah Detensi Imigrasi Makassar}

Warga negara asing adalah seseorang yang tinggal dan menetap di negara tertentu namun bukan berasal dari negara tersebut juga tidak secara resmi terdaftar sebagai warga Negara. Aturan yang mengatur tentang warga negara asing diantaranya ;

Undang - Undang Nomor 6 Tahun 2011 tentang Keimigrasian. Berdasarkan Pasal 1 ayat (1) Keimigrasian adalah hal ihwal lalu lintas orang asing yang masuk atau keluar wilayah indonesia serta pengawasannya dalam rangka menjaga tegaknya kedaulatan negara. Dalam Undang-Undang tersebut juga mengatur tentang Orang Asing, pada pasal 1 aya (9) Orang Asing adalah orang yang bukan warga negara Indonesia. Dalam Undang-undang tersebut juga mengatur tentang Rumah Detensi Imigrasi, Rumah Detensi Imigrasi adalah unit pelaksana teknis yang menjalankan fungsi keimigrasian sebagai tempat penampungan sementara bagi orang asing yang dikenai tindakan administratif Keimigrasian. Dalam Undang-undang tersebut juga mengatur tentang Deteni, pada pasal 1 ayat (35) Deteni adalah Orang Asing penghuni Rumah Detensi Imigrasi atau Ruang Detensi Imigrasi yang telah mendapatkan keputusan pendetensian dari pejabat Imigrasi.

Peraturan Pemerintah Nomor 31 Tahun 2013 tentang Peraturan Pelaksana Keimigrasian. dalam peraturan Pemerintah Tersebut Mengatur Tentang Keimigrasian, pada pasal 1 ayat (1) keimigrasian merupakan hal ihwal lalu lintas orang yang masuk atau keluar wilayah Negara Republik Indonesia serta pengawasan orang asing di wilayah negara Republik Indonesia dalam rangka menjaga tegaknya kedaulatan negara. Dalam Peraturan pemerintah tersebut juga mengatur tentang Orang Asing, pada pasal 1 ayat (3) Orang Asing adalah orang yang bukan warga negara Indonesia. Dalam Peraturan pemerintah tersebut juga mengatur tentang Rumah Detensi Imigrasi, pada pasal 1 ayat (24) Rumah Detensi Imigrasi adalah unit pelaksana teknis yang menjalankan fungsi keimigrasian sebagai tempat penampungan sementara bagi orang asing yang dikenai tindakan administratif Keimigrasian. Dalam Peraturan Pemerintah tersebut juga mengatur tentang Tindakan Administratif Keimigrasian, pada pasal 1 ayat (23) Tindakan Administratif Keimigrasian adalah sanksi administratif yang ditetapkan pejabat imigrasi terhadap Orang Asing diluar proses peradilan. Dalam Peraturan Pemerintah tersebut juga mengatur tentang Deteni, pada pasal 1 ayat (26) Deteni adalah Orang Asing penghuni Rumah Detensi Imigrasi atau Ruang Detensi Imigrasi yang telah mendapatkan keputusan pendetensian dari pejabat Imigrasi.

Peraturan Menteri Hukum dan Hak Asasi Manusia Nomor 4 Tahun 2017 tentang Tata Cara Pengawasan Keimigrasian, dalam Peraturan Menteri Tersebut Mengatur Tentang Keimigrasian, pada pasal 1 ayat (1) keimigrasian merupakan hal ihwal lalu lintas orang yang 
masuk atau keluar wilayah Negara Republik Indonesia serta pengawasan orang asing di wilayah negara Republik Indonesia dalam rangka menjaga tegaknya kedaulatan negara. Dalam Peraturan Menteri tersebut juga mengatur tentang Orang Asing, pada pasal 1 ayat (4) Orang Asing adalah orang yang bukan warga negara Indonesia. Dalam Peraturan pemerintah tersebut juga mengatur tentang Rumah Detensi Imigrasi, pada pasal 1 ayat (21) Rumah Detensi Imigrasi adalah unit pelaksana teknis yang menjalankan fungsi keimigrasian sebagai tempat penampungan sementara bagi orang asing yang dikenai tindakan administratif Keimigrasian.

Peraturan Direktur Jendral Imigrasi

Nomor IMI.1917-OT.02.01 Tahun 2013

Tentang Standar Operasional Prosedur Rumah Detensi Imigrasi. Maksud dari dibuatnya Peraturan Direktur Jendral Imigrasi Nomor IMI.1917-OT.02.01 Tahun 2013 Tentang Standar Operasional Prosedur Rumah Detensi Imigrasi yaitu Memberikan pedoman dan keseragaman bagi petugas imigrasi pada Rumah Detensi Imigrasi dalam pendetensian, pengisolasian, pendeportasian, pemulangan, pemindahan, dan fasilitasi penempatan ke negara ketiga terhadap Orang Asing di Wilayah Indonesia yang melakukan pelanggaran ketentuan peraturan perundang-undangan, serta fasilitasi penempatan ke negara ketiga bagi Deteni secara tertib dan dapat dipertanggungjawabkan. Adapun tujuan dari dibuatnya Peraturan Direktur Jendral Imigrasi Nomor IMI.1917-OT.02.01 Tahun 2013 Tentang Standar Operasional Prosedur Rumah Detensi Imigrasi yaitu Terciptanya standardisasi pendetensian, pengisolasian, pendeportasian, pemulangan, pemindahan, dan fasilitasi penempatan ke negara ketiga terhadap Orang Asing di Wilayah Indonesia yang melakukan pelanggaran ketentuan peraturan perundangundangan, serta fasilitasi penempatan ke negara ketiga bagi Deteni yang berada di Rumah Detensi Imigrasi.

Dari hasil analisis aturan yang mengatur tentang Warga Negara Asing terdiri dari Undang-undang Republik Indonesia Nomor 6 Tahun 2011 tentang Keimigrasian dimana aturan tersebut terdiri dari XV BAB dan 145 Pasal, yang mengatur tentang 1) ketentuan Umum; 2) Pelaksanaan Fungsi Keimigrasian; 3) masuk dan keluar wilayah Indonesia; 4) dokumen perjalanan Republik Indonesia; 5) visa, tanda masuk dan izin tinggal; 6) pengawasan keimigrasian; 7) tindakan administrasi keimigrasian; 8) rumah detensi imigrasi dan ruang detensi imigrasi; 9) pencegahan dan penagkalan; 10) penyidikan; 11) ketentuan pidana; 12) biaya; 13) ketentuan pidana; 14) ketentuan peralihan; 15) ketentuan penutup. Dari analisis tersebut disimpulkan bahwa Undang-undang Republik Indonesia Nomor 6 Tahun 2011 mengatur tentang Keimigrasian secara umum.

Analisis selanjutnya yaitu Peraturan Pemerintah Republik Indonesia Nomor 31 Tahun 2013 tentang Peraturan Pelaksanaan Keimigrasian dimana aturan tersebut terdiri dari $\mathrm{X}$ BAB dan 258 Pasal, yang mengatur tentang 1) ketentuan Umum; 2) Persyaratan dan tata cara masuk dan keluar wilayah Indonesia; 3) Persyaratan dan tata cara pemberian, penarikan, pembatalan, pencabutan, penggantian, serta pengadaan belanko dan standardisasi dokumen perjalanan Republik Indonesia; 4) Persyaratan dan tata cara permohonan, jenis kegiatan, dan jangka waktu penggunaan visa; 5) Persyaratan dan tata cara permohonan, pemberian, jangka waktu, penolakan, dan pembatalan, dan alih status izin tinggal; 6) Pengawasan keimigrasian, inteligen keimigrasian, rumah detensi imigrasi dan ruang detensi imigrasi, serta penanganan terhadap korban perdagangan orang dan penyeludupan manusia; 7) Pelaksanaan pencegahan dan penangkalan; 8) Persyaratan dan tata cara pengangkatan PPNS, keimigrasian dan administrasi penyidikan keimigrasian; 9) Ketentuan Peralihan; 10) Ketentuan Penutup. Dari analisis tersebut disimpulkan bahwa Peraturan Pemerintah Republik Indonesia Nomor 31 Tahun 2013 mengatur tentang Peraturan Pelaksanaan Keimigrasian.

Analisis selanjutnya yaitu Peraturan Hukum dan Hak Asasi Manusia Republik Indonesia Nomor 4 Tahun 2017 tentang Tata Cara Pengawasan Keimigrasian dimana aturan tersebut terdiri dari VI BAB dan 68 Pasal, yang mengatur tentang 1) ketentuan Umum; 2) Pengawasan Keimigrasian; 3) Tata cara Pengawasan keimigrasian terhadap WNI; 4) Tata cara pengawasan keimigrasian terhadap orang asing; 5) Pengawasan keimigrasian terhadap penjamin; 6) Ketentuan Umum. Dari analisis tersebut disimpulkan bahwa Peraturan Hukum dan Hak Asasi Manusia Republik Indonesia Nomor 4 Tahun 2017 hanya mengatur tentang Tata Cara Pengawasan Keimigrasian

Analisis selanjutnya yaitu Peraturan Direktur Jenderal Imigrasi Nomor IMI.1917OT.02.01 Tahun 3013 Tentang Standar 
Operasional Prosedur Rumah Detensi Imigrasi dimana aturan tersebut mengatur tentang pelayanan kesehatan dan makanan yang di atur pada Bagian V Pelaksanaan point 2 Pelayanan deteni bagian (c) Pelayanan kesehatan dan kebersihan bertugas mengupayakan Kesehatan dan kebersihan dengan melakukan; 1) pemeriksaan kesehatan Deteni secara rutin; Pelayanan makanan juga di atur dalam Peraturan Direktur Jendral Imigrasi Nomor IMI.1917OT.02.01 Tahun 2013 Tentang Standar Operasional Prosedur Rumah Detensi Imigrasi. Bagian V Pelaksanaan point 2 Pelayanan deteni bagian (b) penyediaan kebutuhan makanan dan minuman mengatur tentang penyediaan 1) makanan dan minuman yang layak sebanyak tiga kali dalam sehari.

Dari analisis tersebut di atas dapat disimpulkan bahwa aturan yang mengatur tentang Warga Negara Asing terdiri dari Undang-undang, Peraturan Pemerintah, Peraturan Menteri, yang kesemuanya mengatur tentang Warga Negara Asing Secara keseluruhan. Dan aturan yang mengatur tentang pelayanan kesehatan dan makanan di atur secara khusus di dalam Peraturan Direktur Jendral Imigrasi Nomor IMI.1917-OT.02.01 Tahun 2013 Tentang Standar Operasional Prosedur Rumah Detensi Imigrasi.

\section{Pemenuhan Hak Mendapatkan Pelayanan Kesehatan dan Makanan Bagi Deteni di Rumah Detensi Imigrasi Makassar}

Hak mendapatkan pelayanan kesehatan dan makanan adalah hak setiap manusia, hak tersebut bersifat universal yang berarti melampaui batas-batas negara, kebangsaan dan ditujukan pada setiap orang baik miskin maupun kaya, laki-laki atau perempuan, normal atau penyandang cacat. Dikatakan universal karena hak-hak ini dinyatakan sebagai bagian dari kemanusiaan setiap sosok manusia, tak peduli apapun warna kulitnya, jenis kelaminnya, usianya, latar belakang kultural dan agama ataupun kepercayaan spiritualnya. Sebagai norma yang ditujukan bagi pengakuan hak semua orang, maka setiap orang baik sendirisendiri maupun kelompok perlu menggali dasardasar pemenuhan hak mendapatkan pelayanan kesehatan dan makanan bagi Deteni dan selanjutnya menuntut peningkatan pelaksanaannya.

\section{a. Pemenuhan Hak Mendapatkan Pelayanan Kesehatan bagi Deteni di Rumah Detensi Imigrasi Makassar}

Kesehatan merupakan kondisi sejahtera dari badan, jiwa, dan sosial yang memungkin setiap Deteni produktif secara ekonomis. Kesehatan merupakan dasar dari diakuinya derajat kemanusiaan. Tanpa kesehatan, Deteni menjadi tidak sederajat secara kondisional. Tanpa kesehatan, Deteni tidak akan mampu memperoleh hak-haknya yang lain. Tanpa kesehatan Deteni tidak bisa menikmati kehidupannya sebagai manusia sepenuhnya.

Mengenai pemenuhan hak mendapatkan pelayanan kesehatan bagi Deteni di Rumah Detensi Imigrasi yang menurut Standar Operasional Prosedur Rumah Detensi Imigrasi yaitu pada point $\mathrm{V}$ tentang Pelayanan Deteni bagian $\mathrm{C}$ "Petugas mengupayakan pemeriksaan kesehatan dilakukan secara rutin. Kepala rudenim menambahkan pemeriksaan kesehatan secara rutin dilakukan minimal satu kali dalam satu bulan.

Berdasarka hasil analisis yang dilakukan dapat disimpulkan bahwa pelayanan kesehatan yang dilakukan Rumah Detensi Imigrasi Makassar sudah Optimal pelaksanaannya dilihat dari data pemeriksaan kesehatan yang dilakukan selama 1 tahun, dari data tersebut didapat dilihat bahwa pemeriksaan kesehatan terlaksana 11 kali pemeriksaan kesehatan dan satu bulan tidak terlaksanan dengan alasan bulan puasa dan hari raya Idhul Fitri.

\section{b. Pemenuhan Hak Mendapatkan Makanan bagi Deteni di Rumah Detensi Imigrasi Makassar \\ Hak untuk mendapatkan makanan} adalah seperangkat hak yang melekat pada hakikat dan keberadaan manusia sebahai mahluk Tuhan yang Maha Esa dan merupakan anugerahnya yang wajib terpenuhi dan dijunjung tinggi dan dipenuhi oleh setiap orang demi kehormatan serta perlindungan harkat dan martabat setiap manusia.

Hak untuk mendapatkan makanan yang layak dalah hak setiap Deteni yang ditempatkan di Rumah Detensi Imigrasi Makassar karena hal tersebut diatur di dalam Peraturan Direktur Jendral Imigrasi Tentang Standar Operasional Prosedur Rumah Detensi Imigrasi yaitu pada point $\mathrm{V}$ tentang Pelayanan Deteni bagian B "Petugas mengupayakan penyediaan makanan dan minuman yang layak sebanyak tiga kali sehari. 
Berdasarka hasil analisis yang dilakukan dapat disimpulkan bahwa penyediaan makanan dan minuman yang dilakukan Rumah Detensi Imigrasi kurang Optimal Pelaksanaanya karena terbukti dari hasil tabel daftar menu makanan 10 hari tidak terapkan dan dipertegas dari wawancara dengan Deteni ternyata makanan tidak di berikan tiga kali sehari melainkan yang diberikan hanya bahan makanan yang kemudian Deteni sendiri yang memasaknya.

\section{Faktor yang mempengaruhi dalam Pemenuhan Hak Mendapatkan Pelayanan Kesehatan dan Makanan bagi Deteni Di Rumah Detensi Imigrasi Makassar}

Setiap orang pasti menginginkan pelayanan yang ideal tapi realitas yang terjadi di lapangan sering bertolak belakang dari apa yang diharapkan, begitupun dengan keberhasilan pemenuhan hak mendapatkan pelayanan kesehatan dan makanan di Rumah Detensi Imigrasi Makassar tentunya dipengaruhi dengan berbagai faktor penentu. Berdasarkan hasil wawancara dan observasi yang dilakukan oleh peneliti ternyata pemenuhan hak mendapatkan pelayanan kesehatan dan makanan bagi Deteni di Rumah Detensi Imigrasi masih dipengaruhi oleh beberapa faktor, yaitu sebagai berikut :

\section{a. Faktor Pendukung dalam Pemenuhan Hak Mendapatkan Pelayanan Kesehatan dan Makanan bagi Deteni Di Rumah Detensi Imigrasi Makassar \\ Beberapa faktor pendukung dalam} Pemenuhan Hak Mendapatkan Pelayanan Kesehatan dan Makanan bagi Deteni Di Rumah Detensi Imigrasi Makassar diantaranya:

1) Pegawai Rumah Detensi Imigrasi Makassar yang memadai

Keberhasilan suatu instansi akan berhasil dalam melaksanakan pelayanan yang baik sesuai dengan tugas dan fungsi jika didukung dengan Jumlah pegawai yang memadai. Pegawai Rumah Detensi Imigrasi Makassar haruslah cukup jumlahnya sesuai dengan kebutuhan serta memiliki keterampilan yang memadai sesuai dengan ketentuan tugastugas, dan fungsi di Rumah Detensi Imigrasi Makassar.

Berdasarkan hasil analisis yang dilakukan penulis dapat disimpulkan bahwa Jumlah pegawai saat ini di Rumah Detensi Imigrasi makassar berjumlah 52 orang pegawai terdiri dari 13 orang pegawai perempuan dan 39 pegawai laki-laki, Dengan cukupnya jumlah pegawai di rumah Detensi Imigrasi Makassar maka hal tersebut menjadi faktor pendukung dalam pemenuhan hak pelayanan kesehatan dan makanan bagi deteni di Rumah Detensi Imigrasi Makassar.

\section{b. Faktor Penghambat dalam Pemenuhan Hak Mendapatkan Pelayanan Kesehatan dan Makanan bagi Deteni Di Rumah Detensi Imigrasi Makassar}

Beberapa faktor pendukung dalam Pemenuhan Hak Mendapatkan Pelayanan Kesehatan dan Makanan bagi Deteni Di Rumah Detensi Imigrasi Makassar diantaranya:

\section{1) Anggaran yang terbatas}

Anggaran atau biaya yang dimaksud adalah segala sesuatu yang membutuhkan biaya dalam proses pemenuhan hak mendapatkan pelayanan kesehatan dan makanan atau biaya yang dibutuhkan dan dikeluarkan oleh Rumah Detensi Imigrasi Makassar. Anggaran biaya yang diperlukan Rumah Detensi Imigrasi Makassar untuk melaksanakan peran dan fungsinya dalam hal pemenuhan hak pelayanan kesehatan dan makanan bukanlah sedikit, sehingga sangat perlu diperhatikan dalam proses penganggaran dan pemenuhannya.

Anggaran merupakan suatu hal yang sangat berperan dalam setiap pelaksanaan kegiatan. Tanpa adanya anggaran di setiap pelayanan maka suda pasti pelaksanaan pelayanan tersebut tidak dapat dilaksanakan dengan baik. Tidak bisanya di prediksi jumlah Deteni yang akan di tempatkan di Rumah Detensi Imigrasi menjadikan susahnya penetapan anggaran yang dilakukan pada saat pengajuan penganggaran, terlebih lagi anggaran yang cair terkadang tidak sesuai dengan kebutuhan anggaran yang di butuhkan.

\section{2) Keterbatasan Sarana dan Prasarana}

Pelayanan kesehatan dan makanan merupakan hak dasar setiap orang termasuk Deteni yang harus di penuhi dalam pelaksanaanya. Untuk dapat memaksimalkan pelayanan kesehatan dan makanan harusnya di dukung oleh sarana dan prasarana yang memadai, sehingga pemenuhan hak tersebut terlaksana dengan baik tanpa adanya penghilangan hak setiap Deteni yang ada di Rumah Detensi Imigrasi Makassar. 
Dari hasil analisis yang telah dilakukan penulis dapat disimpulkan bahwa keterbatasan sarana dan prasarana menjadi faktor penghambat dalam pemenuhan hak mendapatkan pelayanan kesehatan dan makanan bagi Deteni di Rumah Detensi Imigrasi Makassar. Terbukti masih kurangnya sarana dan prasarana kesehatan seperti Lampu Periksa, Alat Oksigen, Timbangan, Tensimeter, Termometer dan Alat Infus, sedangkan untuk memberikan pelayanan makanan harusnya petugas rudenim lebih memperhatikan sarana dan prasarana dapur seperti Termos, Rice Cooker, Dispenser, Blender dan Kulkas.

\section{SIMPULAN DAN SARAN}

Berdasarkan hasil penelitian dan pembahasan dapat ditarik kesimpulan sebagai berikut :

1. Pengaturan hukum Warga Negara Asing ( Deteni ) diatur didalam Undang-Undang Nomor 6 Tahun 2011 Tentang Keimigrasian, Peraturan Pemerintah Nomor 31 Tahun 2013, Peraturan Menteri Hukum dan Hak Asasi Manusia Nomor 4 Tahun 2017 tentang Tata Cara Pengawasan Keimigrasian, dan Peraturan Direktur Jendaral Imigrasi Nomor IMI.1917-OT.02.01 Tahun 2013 Tentang Standar Operasional Prosedur Rumah Detensi Imigrasi.

2. Pemenuhan hak mendapatkan pelayanan kesehatan bagi Deteni di Rumah Detensi Imigrasi Makassar sudah Optimal pelaksanaannya dilihat dari data pemeriksaan kesehatan yang dilakukan selama 1 tahun, dari data tersebut didapat dilihat bahwa pemeriksaan kesehatan terlaksana 11 kali pemeriksaan kesehatan dan satu bulan tidak terlaksanan dengan alasan bulan puasa dan hari raya Idhul Fitri. Sedangkan pelayanan makanan bagi Deteni di Rumah Detensi Imigrasi Makassar, Kurang optimal dalam pelaksanaannya kurang Optimal Pelaksanaanya karena terbukti dari hasil tabel daftar menu makanan 10 hari tidak terapkan dan dipertegas dari wawancara dengan Deteni ternyata makanan tidak di berikan tiga kali sehari melainkan yang diberikan hanya bahan makanan yang kemudian Deteni sendiri yang memasaknya.

3. Faktor yang mempengaruhi pemenuhan hak mendapatkan pelayanan kesehatan dan makanan bagi Deteni di Rumah Detensi Imigrasi Makassar, meliputi beberapa faktor, diantaranya yaitu, a) Faktor pendukung sebagai berikut; 1) Pegawai Rumah Detensi Imigrasi Makassar yang memadai, b) Faktor penghambat sebagai berikut; 1) Anggaran yang terbatas dan 2) keterbatasan sarana dan prasarana.

Adapun saran dalam penelitian adalah:

1. Bagi lembaga terkait di harapkan dapat melaksanakan aturan hukum yang sudah ada agar pemenuhan hak mendapatkan pelayanan kesehatan dan makanan bagi Deteni di Rumah Detensi Imigrasi Makassar dapat terlaksana dengan Optimal.

2. Bagi Rumah Detensi Imigrasi diharapkan lebih meningkatkan pelayanan kesehatan dengan cara memeriksa kesehatan deteni secara rutin satu kali dalam satu bulan serta meningkatkan pelayanan makanan dengan cara menyediakan makanan yang layak tiga kali sehari.

3. Diharapkan pihak Rumah Detensi Imigrasi mengambil tindakan terhadap factor Penghambat dalam pemenuhan hak mendapatkan pelayanan kesehatan dan makanan bagi Deteni terkhususnya dalam hal meningkatkan fasilitas sarana dan prasarana demi terpenuhinya hak pelayanan kesehatan dan makanan bagi semua Deteni.

\section{DAFTAR PUSTAKA}

Buku:

Abdul Bari, 2002. Buku Acuan Nasional Pelayanan Kesehatan Maternal dan Neonatal, Yayasan Bina Pustaka, Jakarta.

Afandi Dedi, 2008. Hak Atas Kesehatan dalam Perapektif HAM. Jilid 2 No. 1 Maret 2008.

Amiruddin dan Zainal Asikin. 2013. Pengantar Metode Penelitian Hukum. Jakarta: Rajawali Pers

Azrul Anwar. 2006. Pengantar Administrasi Kesehatan, edisi ketiga. Jakarta: Binarupa Aksara

Hamidi, Jazim dan Christian, Charles. 2015. Hukum Keimigrasian Bagi Orang Asing di Indonesi. Jakarta :Sinar Grafika.

Indra Perwira, 2009. Kesehatan Sebagai Hak Asasi Manusia, dalam Bagir Manan, et.al., Dimensi-Dimensi Hukum Hak Asasi Manusia, PSKN FH UNPAD, Bandung. 
Komisi Nasional Hak Asasi Manusia, 2009. Komentar Umum Kovenan Internasional Hak Sipil dan Politik \& Komentar Umum Kovenan Hak Ekonomi Sosial dan Budaya, Jakarta: Komnas HAM.

Kusumaatmadja, Mochtar. 2003. Pengantar Hukum Internasional. Bandung: Alumni.

M. Iman Santoso, 2012. Perspektif Imigrasi dalam Migrasi Manusia. Bandung: Pustaka Reka Cipta.

Najaruddin Safaat, 2008. Analisis Penegakan Hukum Keimigrasian Pada Kantor Imigrasi Klas I Khusus Soekarno Hatta Berdasarkan Undang-Undang Keimigrasian dan Hukum Acara Pidana, Thesis Universitas Indonesia.

Rahardjo, Satjipto. 2009. Masalah Penegakan Hukum Suatu Tinjauan Sosiologis. Bandung: CV Sinar Baru.

Soekanto, Soerjono. 2011. Penelitian Hukum Normatif. Jakarta: PT Raja Grafindo Persada.

2014. Faktor-faktor yang mempengaruhi penegakan hukum. Jakarta: PT Raja Grafindo.

Supramono, Gatot. 2012. Hukum Orang Asing di Indonesia. Jakarta Timur : Sinar Grafika.

Sri Badini Amidjojo, 2013. Perlindungan Hukum Terhadap pengungsi Berdasarkan Nonvensi Jenewa 1951, Badan Pembinaan Hukum Nasional Departemen Kehakiman dan HAM, Jakarta.

Skripsi/ Jurnal:

Safaat, Najarudin. 2008. (Tesis). Analisis Penegakan Hukum Keimigrasian Pada Kantor Imigrasi Klas I Khusus Soekarno Hatta Berdasarkan Undang-Undang Keimigrasian dan Hukum Acara Pidana. Universitas Indonesia. Depok.

Wilis, Ratna. 2009. (Tesis). Pengawasan dan Penindakan Keimigrasian Terhadap Izin Tinggal Orang Asing di Indonesia Studi Wilayah Kantor Imigrasi Kelas I Khusus Medan. FH USU. Medan.

Villian Febri Morradi, 2015 (Tesis). Rumah Detensi Imigrasi dalam Perlindungan Hak Asasi Manusi Warga Negara Asing Studi Pada Rumah detensi Imigrasi Semarang, UNES, Semarang.

PeraturanPerundang-undangan :
Undang - Undang Dasar Negara Republik Indonesia Tahun 1945

Undang-Undang Nomor 39 Tahun 1999 tentang Hak Asasi Manusia Lembaran Negara Republik Indonesia Tahun 1999 Nomor 164

Undang-Undang Nomor 11 tahun 2005 tentang Ratifikasi Kovenan Hak Ekonomi, Sosial dan Budaya Lembaran Negara Republik Indonesia Tahun 2005 Nomor 118

Undang-Undang Nomor 6 Tahun 2011 tentang Keimigrasian Lembaran Negara Republik Indonesia Tahun 2011 Nomor 53

Peraturan Pemerintah Nomor 13 Tahun 2013 Tentang Peraturan Pelaksana Keimigrasian Lembaran Negara Republik Indonesia Tahun 2013 Nomor 68 Tambahan Lembaran Negara Republik Indonesia Nomor 5049

Peraturan Menteri Hukum dan Hak Asasi Manusia Nomor 4 Tahun 2017 Tentang Tata Cara Pengawasan Keimigrasian Lembaran Negara Republik Indonesia Tahun 2017 Nomor 641

Peraturan Direktur Jendral Imigrasi Nomor F1002.PR.02.10. Tahun 2006 tentang Tata Cara Pendetensian Orang Asing

Peraturan Direktur Jendral Imigrasi Nomor IMI1489.UM.08.05 Tahun 2010 tentang Penanganan Imigran Ilegal

Peraturan Direktur Jendral Imigrasi Nomor IMI.1917-OT.02.01 Tahun 2013 tentang Standar Operasional Prosedur Rumah Detensi Imigrasi

\section{Sumberlain :}

Kanavino Ahmad Rizqo 2018.

Pengertianrumahdetensi, URL:

https://news.detik.com/berita/d-

3834609/dilema-menkum-soal-pencari-

suaka-dan-detensi-imigrasi-yang-

terbatas.html, diaksestanggal 03 Januari 2019

Zakky, 2018. Pengertianhakasasimanusia, URL: https://www.zonareferensi.com /pengertian-hak-asasi-manusia/.html, diaksestanggal 27 Desember 2018 